\title{
The Degree of Competition in the UAE Banking Industry
}

\author{
George, Owusu-Antwi \\ Business College Finance and Accounting Department, Dubai Women's College, Dubai, The \\ United Arab Emirates \\ E-mail: georgegowu@yahoo.com \\ Rachna, Banerjee
}

Business College Finance and Accounting Department, Dubai Women's College, Dubai, The United Arab Emirates

Amal, Abeer-Mohammed

Business College Finance and Accounting Department, Dubai Women's College, Dubai, The United Arab Emirates

Mariam Juma, Muna-Habib

Business College Finance and Accounting Department, Dubai Women's College, Dubai, The United Arab Emirates

Received: June 9, 2017 Accepted: July 6, $2017 \quad$ Published: July 17, 2017

doi:10.5296/ifb.v4i2.11593 URL: http://dx.doi.org/10.5296/ifb.v4i2.11593

\begin{abstract}
This paper has made an attempt to assess the degree of competition (or market structure) in the UAE banking sector using the H-statistics established by Panzar-Rosse (1987). Data of six years (2009-2015) have been extracted from various balance sheet and income statements of the banks. Pooled OSL estimator was used to obtain the coefficient. The inputs prices were found to be significant except the input price of labor. Total asset was registered to be positively significant. All other variables were not significant. The results of the study reveal that the UAE banking market structure is characterized by the monopolistic competition. That is, banks earned their revenue as if operating under conditions of monopolistic competition
\end{abstract}


during this period. A robust check was performed to test for validity of PR-model. The results yield E-statistic which is consistent with long-run equilibrium. It is believed that both the small and the larger banks operate relatively equal more in a competitive environment. We recommend that UAE should develop new financial products and services that will provide convenience to customers while improving profitability.

Keywords: Competition, H-statistics, Monopolistic, Monopoly and perfect competition 


\section{Introduction}

The vital task of banking in the economy decrees competition among banks as an essential and appropriate policy concern. Several lessons have challenged to observe the factors and the properties of competition in the banking industry. A precarious step is to determine the degree and the growth of competition. The UAE banks faces a number of strong breezes; broad enhancement in digital technology coupled with new market participants and non-bank-financial institutions. Tightening liquidity, margin compression, rise in loan impairments, increased cost of funding, acute inflation and prolonged period of low oil prices and economic volatility has handcuff the hands of the banks (UAE Central Bank, 2017). Previous years have provided important lessons with regard to factors that has influenced the degree of competition. The relaxation of banking policies and regulations have caused an increase in the number of banks and non-banking institutions, the upshot has led to the concentration in the banking sector. Although concentration has increased, its explicit impact on competition in the UAE banking sector remains a vital question. This study measures the degree of competition in the UAE banking system using the H-statistics put forward by Panzar \& Ross (1987). The Financial system in UAE is broadly bank-based and weakly contestable, therefore, any complete bank failures would have serious infectious consequences in the economy. Competition increases efficiency, lowers prices, and enhances choice and innovation. Competition removes obstructive exercises and lessens margins between deposit and lending rates, thereby cultivating the concert of the banking industry. The question asked is how we can determine the best and most effective way to increase competition within the industry. In this respect, we decided to find the level of competition within the banking industry of UAE. The importance of this study is that it offers an insight into the UAE banking market structure from the competition perspective, which can be useful in the desired growth of the banks and its developed financial markets. The study employed a cross panel data of 18 selected banks in the UAE covering the period from 2009 to 2015. Pooled ordinary least square (POLS) was employed to estimate the coefficients of the PR model. By smearing the Panzar-Rosse procedure for the period 2009-2015, we found the UAE banking market is reliable with monopolistic competition, with values of the H-statistic being less than one (.94). To our knowledge, this is the first paper to use Panzar-Rosse model to measure competition in the UAE banking industry. The rest of the paper is organized as follows: section 2 presents the structure of the UAE banking system. Section 3 focus on the literature while section 4 explores the methodology. Section 5 presents the results and interpretation and section 6 deals with conclusion, recommendation and policy implications.

\section{UAE Banking Structure}

The UAE banking scenery is competitive, with a total of 57 banks consisting of 23 domestic banks and 34 foreign banks working in the country. Of the 23 domestic banks, 17 have either substantial minority or majority ownership by individual emirates. The UAE also have 140 foreign exchange firms and 25 investment firms which have encroached on the traditional hunting grounds. UAE banks have been well represented by a cross-section of foreign banks. Foreign banks are allowed by law to establish representative office in UAE. This has resulted in about thirty-six representative office operating in the UAE at the end of 2004 (Central 
Bank of UAE, 2006). The UAE, not only has the largest banking sector amongst all Arab states but also claims to be the second largest Arab economy with the highest deposits. The total banking sector assets in 2014 mounted at $\$ 631.47$ billion, while the estimated total profits were at $\$ 12.63$ billion, deducing a return on assets of two per cent (UAE Central Bank, 2017). The United Arab Emirates' banking industry falls into two classes. They include foreign and national banks. Each of the two classes is sub-divided into the Emirati National Domestic Banks and Emirati National Conventional Banks. The latter are 15 while the former are 9. The enactment of Federal Law 10 serves as the mainstay of the conventional banking sector. The Federal Law 6 which was propagated in 1985 led to the legalization of Islamic banking system. The Islamic Banking forms a minute constituent of the UAE banking system. The Federal Law 10 established the Central Bank of UAE which provide the authority and responsibilities over Currency Board. The Central Bank also serves as advisory body to the government in terms of monetary and financial matters, such as allotting currency, preserving gold and foreign currency reserves, and framing credit policies. Besides, all the regulations and supervisory duties are under the umbrella of the Central Bank. All Commercial Banks established in UAE are licensed by the Central Bank of UAE and they are subjected to regulations and rules established by the central bank (Central Bank of the UAE, 2017). In 1998 all banks operating in UAE were mandatorily required by the Central bank to use the International Accounting Standards (IAS) for their financial reporting. The local banks in the early 1999 were ordered to establish a clear corporate structures. Besides, UAE banks were required by the Central Bank to maintain at least 10 percent of capital to risk-weighted assets ratio. Based on UAE Central Bank regulations, all UAE bank ownership must be bore by the nationals and needs to be registered as Shareholding Company under the UAE company laws (Central Bank of the UAE, 2017).

\section{Literature Review}

The philosophy of Industrial organization has discovered that the competitiveness of an industry cannot be sized by market structure gages alone, such as the number of institutions, or Herfindahl, and other concentration catalogues (Baumol, Panzar, \& Willig, 1982). Economic concept, proposes that performance measures, such as the size of banking margins, interest spreads, or profitability, do not essentially designate the competitiveness of a banking system. These measures are influenced by dynamics such as a country's macroeconomic performance and stability, the form of degree of taxation of financial intermediation, the quality of the country's information and judicial systems, and risk preferences (Hauner \& Peiris, 2005). According to Hauner \& Peiris quizzing for the degree of active competition necessitates a structural, contestability method which is in line with the industrial organization works. They designated that the degree of competition in the banking system should be sized with the admiration to the actual behavior of bank conduct. The works on the dimension of competition can be divided between the structural and non-structural approaches. The structural method extrapolate the degree of competition from the edifice of the market. The probability of collusion is higher in markets with limited firms and high barriers to entry and exit. The non-structural method, based on the New Empirical Industrial Organization, evaluates the degree of competition directly by witnessing the behavior of 
firms in the market. The non-structural methods of competition can be sub-divided into two parts. The first cohort of NEIO measures, started from the neoclassical model of oligopoly (Vives, 2001). This includes the Lerner index which measures the average degree of pricing power in the market, the conjectural variation model also examines the rivals' reactions if a bank in the market increases its output by one percent, and the Panzar-Rosse model. The Panzar-Rosse (PR) methods depends on the idea that banks will employ different pricing tactics in reply to changes in input costs depending on the market structure in which they operate. Hence, whether a bank operates in competitive markets or aerobics some monopoly power can be deduced from an analysis of that bank's revenue as it responds to changing input prices. In order to measure the competitive structure of the industry, Panzar-Rosse (PR) established the so-called H statistic; which is estimated as the sum of the elasticities of the reduced form (equilibrium) revenues with respect to input prices. The H-statistics measures the percentage change in a bank's equilibrium revenue caused by a one-percent change in all of the bank's input prices (Panzer \& Rosse, 1987). According to PR (1987), market structure is controlled by the magnitude and sign of the $H$-statistic.

Several studies have used H-statistics to determine market structure, for example Negrin, Ocampo \& Struck (2010) used H-statics to determine the market structure of Mexican banks and found the Mexican banks to be operated under monopolistic completion. Abdul Majid \& Fadzlan (2007) also employed PR model to investigate the market structure of Islamic banking industry in Malaysia. Their study found that the Islamic banks in Malaysia earned their revenue in the condition of monopolistic competition. A study by Al-Muharrami (2009) applied the PR model to evaluate the monopoly power of Qatar banking industry during the period 1993 to 2002. His study found the Qatar banking system to be operated under monopolistic competition. He therefore cautioned the Qatar Central Bank not to grant mergers among banks especially large core banks. Rao (2002) carried out a study of 35 banks in the United Arab Emirates from 1998 to 2000. The study entailed an examination of the scope, scale, productivity and cost efficiency of the banks. Rao came to a conclusion that there was significant cost in economies in the United Arab Emirates' banks. Moreover, the findings of the study revealed that the status of the large banks remained intact while that of small banks kept on improving. In addition, Rao found out that small banks had a management committee that could maintain their performance portfolio for a long time when compared to the big banks.

Bikker \& Haaf (2000) also applied the PR model to determine the market structure of banks from 23 European and non-European countries from 1988-1998. Their results described the banking market in the developed world to be operated mainly under monopolistic competition. A study by Matthews, Murinde, \& Zhao (2007) reveals that most of the major British banks operated under monopolistic conditions. An empirical assessment of their studies shows a major structural changes during the period under study. This is consistent with the study by Liu, Molyneux, \& Wilson (2013) who found most British banks to operate under imperfect market competition. Using data from eleven Latin American countries for the period of 1993 to 2000, Yildirim \& Philippatos (2007) found that banks which have proved in many other developed and emerging financial system, was found to be earning their revenue 
under imperfect market competition.

A recent study by Memić (2015) used Panzar-Rosse model to investigate the market structure and a long term equilibrium of the banking market in Bosnia and Herzegovina from 2008-2012. He found Bosnia and Herzegovina banking market to be moderately concentrated market with a decreasing trend and found the banks to be operated under monopoly competition. Coccorese (2013) employed Panzar \& Rosse, H-statistic to evaluate the degree of competition among Italian banks from 1986-1996. His study used total revenues as the dependent variable, and found Italian banks to be operated under the monopolistic competition. Kasman \& Kasman (2015) conducted a study on Turkish banking sector and found negative relationship between competition and non-performance loans. This is consistent with a study by Tan \& Floro (2014) who found a negative relationship between competition and profitability of the banks. Sanya \& Gaertner (2012) provided evidence for low competition in four East African Community countries using PR model. Using a more comprehensive sample of SSA countries Chen (2009), found the degree of competitiveness to be mottled across countries. A study by Buchs \& Mathisen (2005) in Ghana for example, noted that financial restructuring did not sufficiently foster banking competition while Hauner \& Peiris (2008) find contrasting evidence for Uganda. In Africa, Aboagye et al. (2008) also perceive that market power enjoy by banks in Ghana mainly depends on the size, efficiency and the macroeconomic climate in which they operate. Using time series data from 1988 to 2008, Owusu-Antwi \& Antwi (2013) in their studies employed H-statistics to determine degree of competition and economic liberalization in the Ghan banking industry. Their results found the banking industry to be operated under perfect competition environment. This was not consistent with the results obtained by Buchs \& Mathisen (2005) who found Ghanaian banks to be operated under monopolistic competition.

Overall most studies found that banking markets are best labeled as monopolistically competitive. This paper applies the Panzar \& Rosse mechanism to scrutinize competition in the UAE banking industry.

\section{Methodology}

\subsection{Data Sources}

The study used a cross panel data of 18 selected banks in the UAE covering the period from 2009 to 2015. These data were obtained from the annual report of the financial statements of individual banks. The country specific data is obtained from Economic Outlook. The data use in this study includes all the domestic commercial banks that are in operation during the sample period. The total number of UAE banks reached 27 banks in 2014. Foreign banks are excluded from this study due to limitation of available data. An important observation of the period under review is that the major players of the banking sector during the period has increased from 23 to 57 due to the relaxation of regulations that allowed new banks to enter the banking industry without disabling restrictions. In addition, the banking sector's profitability suffered in 2009 as the global economic crisis impacted the region. 


\subsection{Model Specification Analysis}

Panzar \& Rosse method relies on the basis that banks will apply diverse pricing tactics in response to changes in input costs; the tactics relies on the market structure in which they function. Therefore, whether a bank functions in a competitive market or aerobics some monopoly power can be deduced from an analysis of that bank's revenue as it reacts to changing input prices (Claessens \& Laeven, 2004). The nature of competition in the banking segment is assessed using the $\mathrm{H}$-statistic which is the sum of the factor price elasticities which are also derived from the estimation (Panzer \& Rosse, 1987). The assessment is derived from a general banking market model that regulates the stability of output and the number of banks by maximizing profits at both the bank's level and the industry level. In this study we use the P-R model to measure the competitive nature of the UAE banking industry.

Let a bank's revenue function be $\mathrm{R}=\mathrm{R}\left(\mathrm{x}, \mathrm{y}_{1}\right)$ where $\mathrm{x}=\mathrm{a}$ vector of products and $\mathrm{y}_{1}=\mathrm{a}$ vector of exogenous variables shifting the revenue function. Let a bank's cost function be $\mathrm{C}=$ $\mathrm{C}\left(\mathrm{x}, \mathrm{w}, \mathrm{y}_{2}\right)$ where $\mathrm{w}$ is a vector of input prices and $\mathrm{y}_{2}=\mathrm{a}$ vector of exogenous variables shifting the cost function. $\mathrm{y}_{1}$ and $\mathrm{y}_{2}$ may have common variables. Economic concept shows that a firm will be at profit maximization when the marginal revenue equals marginal cost (Bikker \& Boss, 2005). This is written in equation 1

$$
R^{!}\left(x, y_{1}\right)=C^{!}\left(x, w, y_{2}\right)
$$

PR (1987) calculate the sum of the elasticities of the revenue with respect to input prices from the reduced-form revenue equation and define it as the $\mathrm{H}$-statistics in equation 2.

$$
H=\sum(\partial R / \partial w i)(w i / R)
$$

where wi is ith input price. According to Panzar \& Rosse (1987), the deduction about the type of market structure is made, grounded on the magnitude and sign of the $\mathrm{H}$-statistic. That is, both the magnitude and sign are used to distinguish between the diverse market structures. The lucidity behind the H-statistic rests solely on microeconomic philosophy, which sketches how revenues react to changes in input prices for the diverse market structures. It is expected that a perfectly competitive market has an H-statistic equal to one, while the monopolist has a negative $\mathrm{H}$-statistic. The monopolistically competitive market should have an $\mathrm{H}$-statistic that is somewhere between zero and one. The individual bank priced differently in reply to the change in its factor inputs cost. The extent of changes aids to define the degree of market competition in the market (Gajurel \& Pradhan, 2012). The reduced-form revenue equation of Panzar-Rosse model is given in equation 3:

$$
\begin{aligned}
\ln (\text { TRit })=\alpha+\beta_{1} \ln (P L i t) & +\beta_{2} \ln (P K i t)+\beta_{3} \ln (P F i t)+\beta_{4} \ln (T A, i t)+\beta_{5} \ln \left(N P L_{i t}\right)+\beta_{6} \ln \left(T L_{i t}\right) \\
& +\beta_{7} \ln \left(I N F L_{i t}\right)+\beta_{8} \ln \left(G D P G_{i t}\right)+\varepsilon
\end{aligned}
$$

In this study, the dependent variable is specified as total revenue (TR) and is the total interest income and other operating income where $\mathrm{TR}_{\mathrm{it}}$ is bank i's total revenue at time $\mathrm{t}$.. Coccorese (2013) employed total revenue in his model to assess the competitive condition of Italian banking system. The independent variables are the input price of labor (PL1) proxy by expenses on salaries and other staff compensations, divided by total assets; the input price of 
capital (PK2), is all other expenses divided by total assets; the input price of funds (PF3), is the interest expenses divided by total purchased funds) Total assets (TA) are included to see the size effect. The ratio of non-performing loans to total loans (NPL) is included to control for the credit risk effect. Total loans (TL) generally represents the biggest portion of earning of assets and also convey information about bank's risk preference (Yildirim \& Philippatos, 2007). The coefficient of TL is expected to be positive since more interest revenue is generated with increasing levels of loan. To capture macroeconomic conditions, we include the volatility in the rate of inflation and GDP growth to control for macroeconomic uncertainty. In the equation, $i$ is the bank i's at time $t$ and $\varepsilon$ is the error term. All the variables in the equation are in natural $\log$ form. The $H$-statistic is the sum of $\beta_{1}, \beta_{2}$ and $\beta_{3}$. Pooled ordinary least square (POLS) is employed to estimate the coefficients.

\subsection{Robustness Check}

The validity of the PR methodology rests on satisfying the assumption of long-run equilibrium. Equation 4 is use to test the equilibrium position with return on asset (ROA) as the dependent variable measure as net income divided by total asset. Since $R O A$ can possibly take on negative values, it is adjusted by one factor before taking logarithmic transformation. All the independent variables remain the same as in equation 3.

$$
\begin{aligned}
\ln \left(R O A_{i t}\right)=\alpha+\beta_{1} \ln \left(P L_{i t}\right)+ & \beta_{2} \ln \left(P K_{i t}\right)+\beta_{3} \ln \left(P F_{i t}\right)+\beta_{4} \ln \left(T A_{, i t} t\right)+\beta_{5} \ln \left(N P L_{i t}\right)+\beta_{6} \ln \left(T L_{i t}\right) \\
& +\beta_{7} \ln \left(I N F L_{i t}\right)+\beta_{8} \ln (G D P G, i t)+\varepsilon
\end{aligned}
$$

According to Shaffer (1983), ROA ought to be equalized across banks and essentially not to be correlated with input prices in order for long-run equilibrium to hold. Hence the equilibrium $\mathrm{H}$-statistic denoted as $\mathrm{E}$ is given as the sum of $\beta_{1}+\beta_{2}+\beta_{3}$ as shown in equation 5:

$$
E=\sum(\partial R / \partial w i)(w i / R)
$$

If the $H$-statistic is not equal to 0 , the market is considered to be in disequilibrium. The F-statistic is used to test whether $\mathrm{E}=0$, It should be renowned that equilibrium does not mean that competitive conditions are not permissible to change during the sample period.

\section{Results and Interpretation}

The objective of the paper is to measure the degree of competition in the UAE banking system. We achieved this objective by employing PR model with few modifications. Before presenting the model, descriptive statistics for the dependent and the indlependent variables are presented. Table 2 shows the mean values and the standard deviations of the variables under study. The mean value and the standard deviation for the dependents variable, total revenue (TR) remains fairly stable throughout the sample period, whereas the mean values for the ratio of personnel expenses to total assets (PL) and the ratio of operating and administration expenses to total assets (PK) show low values with the same standard deviation. The average figure for the ratio of total interest expenses to total deposits (PF) is considerably high compared to PK and PL. It should be pointed out that the mean values for total assets (TA) are high which seemingly divulges that their sample is not biased toward 
large banks on the average terms. Total assets increased dramatically during the time span under consideration. The mean value for total loans (TL) is relatively high (23.9728) with associated high standard deviation. The mean values for the macroeconomic variables inflation is .297547 with the standard deviation .5918 around the mean. The mean value for the GDP growth remains fairly low 1.196995 with standard deviation of .6487 around the mean.

Table 1. Descriptive statistics

\begin{tabular}{|l|l|l|l|l|l|}
\hline VARIABLES & OBSERVATIONS & MEAN & $\begin{array}{l}\text { STANDARD } \\
\text { DEVIATION }\end{array}$ & MINIMUM & MAXIMUM \\
\hline LNTR & 126 & 20.93696 & 1.57584 & 15.33786 & 23.44641 \\
\hline LNPL & 125 & -4.667965 & 1.208375 & -8.494077 & -1.987084 \\
\hline LNPK & 120 & -4.735524 & 1.152769 & -8.087383 & -.7815531 \\
\hline LNPF & 126 & -3.146151 & 1.912824 & -7.898064 & 0 \\
\hline LNTA & 126 & 24.44654 & 1.221357 & 21.37972 & 26.73101 \\
\hline LNNPL & 126 & 12.97911 & 8.753161 & 0 & 22.24267 \\
\hline LNTL & 126 & 23.9728 & 1.265913 & 20.70795 & 26.32384 \\
\hline LNNFL & 126 & .297547 & .591896 & -.4004776 & 1.410987 \\
\hline LNGDPG & 126 & 1.196995 & .6487379 & 0 & 1.974081 \\
\hline
\end{tabular}

The estimation result of equation 3 with the dependent variables of $\ln \mathrm{TR}_{\mathrm{it}}$ is reported in Table 2 .

Table 2. Regression result of PR model

\begin{tabular}{|c|c|c|c|c|}
\hline \\
\hline \multicolumn{5}{|c|}{\begin{tabular}{l|l} 
Independent Variables & Coefficients
\end{tabular}} \\
\hline $\operatorname{lnPL} \mathrm{L}_{\text {it }}$ & .0462064 & .0713524 & 0.65 & 0.519 \\
\hline $\operatorname{lnPK}$ it & .6574721 & .071439 & 9.20 & 0.000 \\
\hline $\operatorname{lnPF}{ }_{i t}$ & .2303487 & .0472346 & 4.88 & 0.000 \\
\hline $\operatorname{lnTA_{it}}$ & .8483267 & .2693659 & 3.15 & 0.002 \\
\hline $\operatorname{lnNPL}_{\text {it }}$ & .0077916 & .0110841 & 0.70 & 0.484 \\
\hline $\operatorname{lnTL}_{\text {it }}$ & -.0437679 & .2532763 & -0.17 & 0.863 \\
\hline $\operatorname{lnINFL~}_{\text {it }}$ & .0868143 & .1365357 & 0.64 & 0.526 \\
\hline $\operatorname{lnGDP}_{\text {it }}$ & .1265358 & .1265358 & 0.62 & 0.538 \\
\hline Constant & 5.124902 & 1.741169 & 2.94 & 0.004 \\
\hline $\begin{array}{l}\text { R-Square: .7409; Adj } \\
\text { H-statistics: .94 }\end{array}$ & R-Square: & F-statis & $31 ; \mathrm{P}$ & -statistics: 0.000 ; \\
\hline
\end{tabular}

The $\mathrm{R}^{2}$ for the model is $74.09 \%$. The test confirms the chosen independent variables are highly explanatory. The value of F-statistic is 39.31 with p-value is less than 0.05 indicating that the model for UAE banks is significant and the value of adjusted R-square is 0.7220 indicating that the independent variables explain 72.20 percent variation in dependent variable. 


\section{Macrothink}

The unit labor cost (lnPLit) with a coefficient of .0462064 is positive and insignificant indicating that the UAE banks spend less on their human capital. The results found the unit price of capital (lnPK, it) with coefficient .06574721 and the unit funding cost $\left(\operatorname{lnPF}_{i t}\right)$ with coefficient of 2303487 to be positive and statistically significant, indicating that an increase in unit costs of capital or funds leads to higher revenue. This is consistent with the results obtained by Gajurel \& Pradhan (2012). The coefficient for $\left(\ln T A_{i t}\right)$ reported as 8483267 is positive and significant at .05 level. The positive sign of $\mathrm{TA}_{\mathrm{it}}$ indicates the presence of the size effect of bank assets. One of the implications of this result is that larger banks are more efficient than small banks as the total revenue per unit of assets may be lower for the smaller banks (economies of scale). It seems sensible that in order to obtain a more representative and realistic picture of the actual level of competition, those banks with more assets and larger number of customers ought to have a greater impact on the banking market. Bikker \& Groeneveld's (2000) report consists of a model where banks are weighted according to their size in terms of total assets. NPL $\mathrm{N}_{\text {it }}$ had a coefficient of 00077916. This has insignificant positive effect on total revenue. The coefficients of -.0437679 for $1 n \mathrm{TL}_{\text {it }}$ had a negative and insignificant effect on total revenue. Macroeconomic instability, denoted by inflation volatility, seems not to have had a diminishing effect on the banks' revenue performance. This result seems to be a counterintuitive. However, it should be noted that for the sample period, inflation averaged about $29 \%$ with average standard deviation of .59 , implying high volatile inflation outcomes. Furthermore, even under high inflationary conditions, banks tend to devise measures to protect revenues from erosion by adjusting interest rates and fees charged to their customers. Under these conditions, the positive coefficient of INFL $_{\text {it }}$ may be vindicated. The GDP growth rate $\left(\mathrm{GDPG}_{\mathrm{it}}\right)$ is insignificant, however the positive value assume to have an impact on banks' revenue.

The H-statistic, which is the sum of $\beta 1, \beta 2$ and $\beta 3$, is reported as 0.94 and is statistically significant from zero and one at the 5\% level The empirical results lead us to conclude that the UAE banks obtain their revenue under monopolistic competitive during the sample period. Intuitively, the results suggest that factor prices are important for UAE banks in the pricing of bank products and services.

Table 3 presents the estimation results of equation 4 with the dependent variable, $\ln R O A_{i t}$, and the equilibrium tests for UAE banks. 
Table 3. Regression results of long-run equilibrium of PR model

\begin{tabular}{|c|c|c|c|c|}
\hline \multicolumn{5}{|c|}{ Dependent Variable: $\ln \mathrm{ROA}_{\mathrm{it}}$} \\
\hline Independent Variables & Coefficients & Standard Error & t-value & p-value \\
\hline $\operatorname{lnPL} L_{\text {it }}$ & .0002147 & .0812286 & 0.00 & 0.998 \\
\hline $\ln \mathrm{PK}_{\mathrm{it}}$ & .0355048 & .0813272 & 0.44 & 0.663 \\
\hline $\operatorname{lnPF} F_{\text {it }}$ & -.0884078 & .0537725 & -1.64 & 0.103 \\
\hline $\operatorname{lnT} \mathrm{A}_{\mathrm{it}}$ & .3804083 & .30665 & 1.24 & 0.217 \\
\hline $\operatorname{InNPL}_{\text {it }}$ & .021464 & .0126183 & 1.70 & 0.092 \\
\hline $\mathrm{InTL}_{\text {it }}$ & -.2152028 & .02883333 & -0.75 & 0.457 \\
\hline $\operatorname{lnINFL}{ }_{\text {it }}$ & -.0494185 & .1554341 & -0.32 & 0.751 \\
\hline $\operatorname{lnGDPG}_{\text {it }}$ & .0595616 & .1440502 & 0.41 & 0.680 \\
\hline Constant & -4.12458 & 1.982171 & -2.08 & 0.040 \\
\hline \multicolumn{5}{|c|}{$\begin{array}{l}\text { R-square: .1416; Adjusted R-square: 0.0792; F-statistics: 2.27; P-value of F-statistics: } 0.0277 \text {; E-statistics } \\
0.00\end{array}$} \\
\hline \multicolumn{5}{|l|}{ No. of observations: 119} \\
\hline
\end{tabular}

Source: Author's calculations.

The estimates yield the $\mathrm{H}$ values which are consistent with long-run equilibrium $(\mathrm{E}=0)$. It may be inferred from the findings that the UAE banking market was in long-run equilibrium during the sampling which is similar to what Molyneux et al. (1996) found with Japanese commercial banking.

\section{Conclusion}

The paper has addressed a vital theme on competition and market structure in the UAE banking sector for an emerging economy. The foundation of evaluating the degree of competition was the application of Panzar \& Rosse (1987) model. The study has strengthened and extends previous research by estimating the Panzar \& Rosse H- statistic from a reduced revenue regression for the full sample period. By applying the P-R approach for the period 2009-2015, we found that the UAE banking market is reliable with monopolistic competition, with values of the H-statistic being less than one. That is, banks earned their revenue as if operating under conditions of monopolistic competition in the period understudy. The findings are consistent with the results obtained by Al-Muharrami (2009), who found Qatar banks to be operating under monopolistic competition. The study also found the long-run equilibrium of the PR model which justified the validity of the PR model to be the best prescription to determine the degree of competition in the UAE banking market.

\subsection{Recommendation.}

For UAE banks to successfully meet the challenges of the ever-evolving financial environment and acquire global competitiveness, the banks should be on their toes to developed new financial products and services that will suites the customers' needs while improving profitability. In addition they should have a system that identifies and discerns 
customer needs to offer products and services accordingly. For banks to be competitive in today's market, in which information revolves around the customer, they should be able to developed specific products that tailored the needs of the customers and carry out marketing initiatives that will create more value through deep data mining and customer analysis. In addition, UAE banks should cultivate the training of professionals capable of crafting object-centric databases for the classier risk-management systems. There must be constant flow of investment to bring together risk management as well as regulatory interpretation and technological expertise.

\subsection{Policy Implication}

Competition uncluttered opportunities to new actors and advances efficiency, to this effect the government should encourage liberalization and competition in the banking sector since competition will lead to improving adjudication and financial market limpidity. For the consumer, it needs healthier and economical services which will lead to a higher consumer surplus. As the local banks becomes more profitable, competition will become more ferocious, in the light of this, UAE banks will have to put a yardstick in the industry against the world's best performers and clasp up with international banking practices. The intensity of competition will cause most of the banks to move from intermediation operations to disintermediation banking, for their revenue, in view of this banks should be more diversifiable to the promising sectors of the economy. In the world of competition banks flourish with business and consumers' sureness. Higher sureness is achieved through market pellucidity and adjudication. However, the execution of sound regulations and monitored competition policies are indispensable. The hero of the government in this respect is imperative. The growth of the financial market is associated with complicated regulation which requires strong monetarization by the government. International standards serves as the general guidelines in this respect. In this regards, it is the need for the local financial market to achieve the level of financial standard that will be in line with international standard. This will ease the local banks to be able to tap the resources in the international financial markets. The ultimate goal of the firm is to maximize shareholders wealth. In this respect banks will strive to offer higher returns to shareholders. In this case, banks will have to compete to offer higher returns to shareholders. Severe competition owing to lower entry barriers on foreign banks might lead, in the medium term, to the arrival of new comers and consolidation of existing ones. In the event of competition, the UAE banking sector will be engaged in a race in which each contestant is trying to offer healthier and quicker services. However, banks will then have an enticement to take on high risk projects. In the long run, more consolidation in the banking industry is likely to occur. Larger banks would prefer to takeover or merge with another bank rather than spend the money to market and advertise to people.

\section{References}

Abdul Majid, M. Z., \& Fadzlan, S. (2007). Market structure and competition in emerging market: evidence from Malaysian Islamic Banking industry. Munich Personal RePEc Archive. MPRA Paper No. 12126, 1-27. [Online] Available: http://mpra.ub.uni-muenchen.de/12126/

Aboagye, A. Q., Akoena, S., Antwi-Asare, T., \& Gockel, A. (2008). Explaining the market 
power of Ghanaian banks. South African Journal of Economics, 76, 569-585. https://doi.org/10.1111/j.1813-6982.2008.00221.x

Al-Muharrami, S. (2009). Analysis of competitiveness in Qatar banking industry. International Journal of Business Innovation and Research, 3(2), 168-181. https://doi.org/10.1504/IJBIR.2009.022753

Al-Muharrami, S., Matthews, K. \& Khabari, Y. (2006). Market structure and competitive conditions in the Arab GCC banking system. Journal of Banking \& Finance, 30, 3487-3501. https://doi.org/10.1016/j.jbankfin.2006.01.006

Baumol, W., Panzer, J., \& Willig, R. (1982). Contestable Markets and the Theory of Industry Structure. San Diego: Harcourt Brace Jovanovich.

Bikker, J. A., \& Boss, J. W. B. (2005). Competition and efficiency in banking: International comparisons. Economic \& Financial Modelling, 103-139.

Bikker, J. A., \& Groeneveld, J. M (2000). Competition and concentration in the EU banking industry. Kredit und Kapital, 33, 62-98.

Bikker, J. A., \& Haaf, K. (2002). Competition, concentration and their relationship: an empirical analysis of the banking industry. Journal of Banking and Finance, 26, 2191-2214. https://doi.org/10.1016/S0378-4266(02)00205-4

Buchs, T., \& Mathisen, J. (2005). Competition and efficiency in banking behavioral evidence from Ghana (IMF Working Paper No. WP/05/07). Washington, DC: International Monetary Fund.

Central Bank of UAE. (2006). [Online] Available: http://www.centralbank..ae/

Central Bank of UAE. (2013). Financial Stability Report of UAE.

Central Bank of UAE. (2017).

Chen, C. (2009). Bank efficiency in Sub-Saharan African middle-income countries. IMF Working Paper, WP/09/14. International Monetary Fund (IMF). https://doi.org/10.5089/9781451871616.001

Claessens, S., \& Laeven, L. (2004). What drives bank competition? Some international evidence. Journal of Money, Credit and Banking, 36(3), 563-583. https://doi.org/10.1353/mcb.2004.0044

Coccorese, P. (2013). Assessing the competitive conditions in the Italian banking system: some empirical evidence. PSL Quarterly Review, 51(205) 171-191.

Gajurel, D. P., \& Pradhan, R. S. (2012). Concentration and Competition in Nepalese Banking. Journal of Business, Economics \& Finance, 1(1).

Hauner, D., \& Peiris, S. (2008). Banking efficiency and competition in low income countries: The case of Uganda. Applied Economics, 40, 2703-2720. Retrieved September 2006, from International Monetary Fund. https://doi.org/10.1080/00036840600972456 
Hauner, D., \& Peiris, S. J. (2005). Bank efficiency and competition in low-income countries: The case of Uganda (IMF Working Paper No. 05/240). Washington, DC: International Monetary Fund.

Kasman, S., \& Kasman, A. (2015). Bank Competition, Concentration and Financial Stability in the Turkish Banking Industry. Economic Systems, 39(3), 502-517. https://doi.org/10.1016/j.ecosys.2014.12.003

Liu, H., Molyneux, P., \& Wilson, J. O. S. (2013). Competition and Stability in European Banking: A Regional Analysis. The Manchester School, 81(2), 176-201. https://doi.org/10.1111/j.1467-9957.2011.02285.x

Matthews, K., Murinde, V., \& Zhao, T. (2007). Competitive conditions among the major British banks. Journal of Banking \& Finance, 31, 2025-2042. https://doi.org/10.1016/j.jbankfin.2006.11.009

Memić, D. (2015) Banking Competition and Efficiency: Empirical Analysis on the Bosnia and Herzegovina Using Panzar-Rosse Model. Business Systems Research, 6(1).

Molyneux, P., Thornton, J., \& Lloyd-Williams, D. M. (1996). Competition and market contestability in Japanese commercial banking. Journal of Economics and Business, 48, 33-45. https://doi.org/10.1016/0148-6195(95)00047-X

Negrín, J. L., Ocampo, D., \& Struck, P. (2010). Competition in the Mexican Bank Credit Market (available in Spanish). In A. C. Sabido (Ed.), Los grandes problemas de México. Microeconomía, El Colegio de México.

Owusu-Antwi, G., \& Antwi, J. (2013). Do Financial Sector Reforms Improve Competition of Banks? An Application of Panzar and Rosse Model: The Case of Ghanaian Banks. International Journal of Financial Research, 4(3). https://doi.org/10.5430/ijfr.v4n3p43

Panzar, J. C., \& Rosse, J. N. (1982). Structure, conduct and comparative statistics (Discussion Paper No. 248). City, ST: Bell Laboratories Economics.

Panzar, J. C., \& Rosse, J. N. (1987). Testing for "monopoly" equilibrium. Journal of Industrial Economics, 35, 443-456. https://doi.org/10.2307/2098582

Rao, A. (2002). Estimation of Efficiency, Scale \& Scope and Productivity Measures of UAE Banks, European Conference of Financial Management Association/ Copenhagen.

Rosse, J. N., \& Panzar, J. C. (1977). Chamberlain vs Robinson: An empirical study of monopoly rents (Discussion Paper No. 90). City, ST: Bell Laboratories Economic.

Sanya, S., \& Gaertner, M. (2012). Competition in the EAC banking system. IMF Working Paper wp/12/32. International Monetary Fund.

Shaffer, S. (1982). A non-structural test for competition in financial markets. In: Proceedings of a Conference on Bank Structure and Competition. Federal Reserve Bank of Chicago, 225-243. 


\section{Macrothink}

Shaffer, S. (1993). A test of competition in Canadian banking. Journal of Money, Credit and Banking, 25(1), 49-61. https://doi.org/10.2307/2077819

Vives, X. (2001). Oligopoly pricing: old ideas and new tools. Cambridge: The MIT press.

Yildirim, H. S., \& Philippatos, G. C. (2007). Restructuring, consolidation and competition in Latin American banking markets. Journal of Banking \& Finance, 31, 629-639. https://doi.org/10.1016/j.jbankfin.2006.06.008

\section{Copyrights}

Copyright for this article is retained by the author(s), with first publication rights granted to the journal.

This is an open-access article distributed under the terms and conditions of the Creative Commons Attribution license (http://creativecommons.org/licenses/by/4.0/) 